\title{
Determination of catechol and quinol in the urine of workers exposed to benzene
}

\author{
O INOUE, ${ }^{2} \mathrm{~K}$ SEIJI, ${ }^{\prime 2} \mathrm{M}$ KASAHARA, ${ }^{2}$ H NAKATSUKA,${ }^{2}$ T WATANABE, ${ }^{2}$ S-G YIN,${ }^{3}$ \\ G-L LI, ${ }^{3}$ S-X CAI,${ }^{3}$ C JIN,${ }^{3}$ M IKEDA ${ }^{2}$ \\ From the Center of Occupational Medicine, ${ }^{1}$ Tohoku Rosai Hospital, and Department of Environmental Health, ${ }^{2}$ \\ Tohoku University School of Medicine, Sendai 980, Japan, and Institute of Occupational Medicine, ${ }^{3}$ Chinese \\ Academy of Preventive Medicine, Beijing, China
}

\begin{abstract}
Time weighted average concentrations of benzene in breathing zone air (measured by diffusive sampling coupled with FID gas chromatography) and concentrations of catechol and quinol in the urine (collected at about 1500 in the second half of a working week and analysed by high performance liquid chromatography) were compared in 152 workers who were exposed to benzene (64 men, 88 women). The concentration of urinary metabolites was also determined in 131 nonexposed subjects ( 43 men, 88 women). There was a linear relation between the benzene concentrations in the breathing zone and the urinary concentrations of catechol and quinol (with or without correction for urine density) in both sexes. Neither catechol nor quinol concentration was able to separate those exposed to benzene at $10 \mathrm{ppm}$ from those without exposure. The data indicated that when workers were exposed to benzene at $100 \mathrm{ppm}$ about $25 \%$ of benzene absorbed was excreted into the urine as phenolic metabolites, of which $13 \cdot 2 \%, 1 \cdot 6 \%$, and $10 \cdot 2 \%$ are phenol, catechol, and quinol, respectively.
\end{abstract}

As early as 1953, Parke and Williams identified catechol and quinol, in addition to phenol, in the urine of rabbits given ${ }^{14} \mathrm{C}$-benzene by mouth. ${ }^{1}$ Regarding the biological monitoring by means of urine analysis, however, attention has been focused on phenol as an indicator of exposure to benzene. ${ }^{2}$ Other phenolic urinary metabolites such as catechol and quinol are ignored, probably because of the technical difficulties in their analysis. A high performance liquid chromatographic (HPLC) method for the simultaneous determination of catechol and quinol ${ }^{34}$ has been applied in our laboratory to the analysis of urine samples obtained from workers exposed to benzene, and the excretion of the two metabolites was related to the intensity of exposure to benzene. The results are presented in this report compared with previous findings ${ }^{5}$ on excretion of phenol.

\section{Materials and methods}

EXAMINEES AND URINE COLLECTION

Urine samples previously analysed for phenol ${ }^{5}$ were used. In brief, urine samples were collected from 152 workers (64 men, 88 women) exposed to benzene and

Accepted 29 May 1987
131 non-exposed workers ( 43 men, 88 women) at 1500 in the second half of a working week. At this time, concentrations of benzene metabolites are expected to reach the maximum in the urine of the workers exposed to benzene throughout the week. ${ }^{6}$

\section{BENZENE CONCENTRATION IN BREATHING ZONE A IR}

The time weighted (seven hour) average exposure measured by diffusive sampling ${ }^{7}$ is cited from a previous publication. ${ }^{5}$ It was assumed that benzene exposure follows a $\log$ normal distribution ${ }^{89}$ and distribution is therefore expressed in terms of geometric mean (GM) and geometric standard deviation (GSD).

\section{HPLC ANALYSIS OF URINE FOR CATECHOL AND QUINOL}

Each urine sample was heated at $100^{\circ} \mathrm{C}$ for one hour in the presence of hydrochloric acid (final concentration, $1.75 \%$ ) for hydrolysis. The hydrolysate, $2.5 \mathrm{ml}$, was added to $0.2 \mathrm{ml}$ of $2 \mathrm{mg} \mathrm{3,5-xylenol} / \mathrm{ml}$ methanol (as an internal standard) and extracted with $3 \mathrm{ml}$ carbon disulphide-diethyl ether (1:1 by volume) by vigorous shaking for five minutes. After centrifugation at $-10^{\circ} \mathrm{C}$ for 10 minutes for separation, the lower 
organic layer was taken, desiccated with $0.5 \mathrm{~g}$ sodium sulphate anhydrate, and evaporated at $25^{\circ} \mathrm{C}$ under a nitrogen stream to dryness. The residue was taken up in $0.5 \mathrm{ml}$ acetonitrile-water ( $3: 7$ by volume), a portion ( 5 to $10 \mu \mathrm{l}$ per injection) of which was applied to HPLC analysis. ${ }^{34}$ The HPLC used was a Hitachi Model 635 equipped with a Hitachi No 3056 column $(3 \mathrm{~mm}$ in inner diameter and $150 \mathrm{~mm}$ in length, kept at $45^{\circ} \mathrm{C}$ ) and an autosampler (Model KSST-60, KyowaSeimitsu Co, Tokyo, Japan). The mobile phase was a mixture of acetonitrile-acetic acid-water (15.0\%:1.5\%:83.5\%, by volume) and was allowed to flow at a rate of $1.5 \mathrm{ml} / \mathrm{min}$. The metabolites were detected spectrophotometrically at $280 \mathrm{~nm}$. The detection limit was $0.5 \mathrm{mg} / 1$ for catechol and $1.0 \mathrm{mg} / 1$ for quinol. In preliminary studies with urine samples rich in catechol and quinol conjugates it was found that the hydrolysis conditions used were optimal and that no benzoquinone (an oxidation product of quinol ${ }^{10}$ ) or 1,2,4-benzenetriol was detected on the chromatogram when urine samples from workers exposed to benzene at high concentrations were analysed. The metabolite concentrations were expressed either with or without correction for creatinine concentration ${ }^{11}$ or for specific gravity of $1.016 .{ }^{12}$ For the evaluation on a group basis, a log normal distribution was assumed. The creatinine concentration was measured colorimetrically ${ }^{13}$ and the specific gravity by refractometry.

When authentic catechol (at five levels up to 1000 $\mathrm{mg} / \mathrm{l}$ ) and quinol (at five levels up to $500 \mathrm{mg} / \mathrm{l}$ ) were dissolved either in water or in 10 control urine samples (of low catechol or quinol contents), urine and water samples gave the same calibration lines; the former values were $97 \cdot 1 \%$ (with a coefficient of variation of $4.6 \%$ ) of the latter for catechol and $101.7 \%$ (with a coefficient of variation of $3.5 \%$ ) for quinol. To examine the reproducibility of the analyses, a urine sample from an exposed subject (containing about 50 $\mathrm{mg}$ catechol and about $250 \mathrm{mg}$ quinol/1) was divided into eight portions and analysed simultaneously. The coefficient of variation was $3 \cdot 6 \%$ for both catechol and quinol analyses.

\section{Results and discussion}

CONCENTRATIONS OF CATECHOL AND QUINOL IN URINE OF THE NON-EXPOSED SUBJECTS

Both the distribution of catechol and quinol concentrations in the urine samples obtained from nonexposed subjects showed positive skewness. The highest frequency of catechol values was in the range of 7-9 $\mathrm{mg} / \mathrm{l}$ and that of quinol concentrations in the range of 1-3 mg/l (fig 1). The mean, mode, and median were determined before and after logarithmic transformation to examine the fitness with normal and log normal distribution. For example, the calculation with the observed catechol values of 88 non-exposed women gave $13 \cdot 3,7 \cdot 5$, and $12 \mathrm{mg} / \mathrm{l}$ as the mean, mode, and median before transformation, and the logarithmic values were $1.04,0.99$, and 1.08 respectively. In the case of quinol the pretransformation values were $7 \cdot 6$, 1.9 , and $5 \mathrm{mg} / \mathrm{l}$ and the logarithmic values $0.62,0.64$, and $0 \cdot 70$. Thus a log normal distribution was assumed for both phenolic compounds for statistical evaluation. The GMs (GSDs in parentheses) of catechol and quinol concentrations in the urine of the non-exposed subjects are summarised in table 1 . The concentrations are given as observed values and the values corrected for creatinine concentrations and for specific gravity. Whereas the GSD was generally less than 2.0 in the case of catechol, a GSD of larger than 4.0 was often observed with quinol, indicating a wider variation in the latter than in the former. There was no significant $(p>0.05)$ sex difference in the levels of the two compounds.
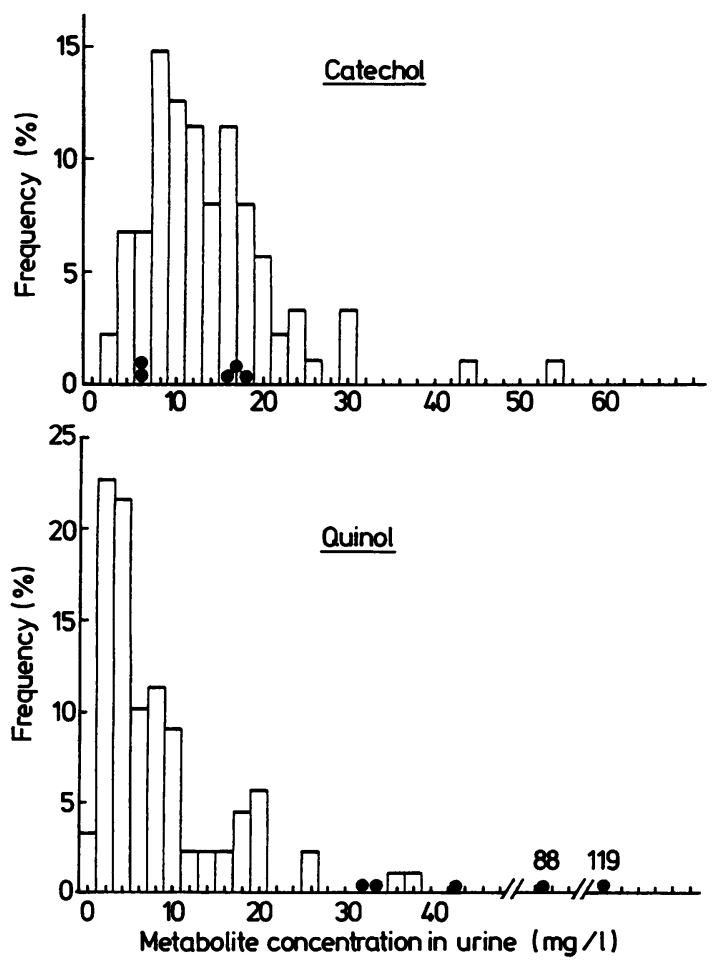

Fig 1 Distribution of catechol and quinol in urine of 88 nonexposed women. Observed values are shown. Catechol and quinol values in urine of five women exposed to benzene at 9-14 ppm are spotted in histograms to show difficulty of separating those exposed to benzene at about 10 ppm from those not exposed. 
Table 1 Catechol and quinol concentrations in urine samples from non-exposed subjects

\begin{tabular}{|c|c|c|c|c|}
\hline \multirow[b]{2}{*}{$\operatorname{Sex}$} & \multirow[b]{2}{*}{$\begin{array}{l}\text { No of } \\
\text { subjects }\end{array}$} & \multirow[b]{2}{*}{$\begin{array}{l}\text { Observed value* } \\
(\mathrm{mg} / \mathrm{l})\end{array}$} & \multicolumn{2}{|c|}{ Value* corrected for } \\
\hline & & & $\begin{array}{l}\text { Creatinine } \\
(\mathrm{mg} / \mathrm{g})\end{array}$ & $\begin{array}{l}\text { Specific gravity } \\
(\mathrm{mg} / \mathrm{l})\end{array}$ \\
\hline \multicolumn{5}{|c|}{ Catechol } \\
\hline $\begin{array}{l}\text { Men + women } \\
\text { Men } \\
\text { Women }\end{array}$ & $\begin{array}{r}131 \\
43 \\
88\end{array}$ & $\begin{array}{r}10.63(1.92) \\
9.77(2.01) \\
11.08(1.87)\end{array}$ & $\begin{array}{l}13.32(1.67) \\
13.03(1.71) \\
13.47(1.65)\end{array}$ & $\begin{array}{l}10.88(1.68) \\
11.42(1.65) \\
10.63(1.69)\end{array}$ \\
\hline \multicolumn{5}{|c|}{ Quinol } \\
\hline $\begin{array}{l}\text { Men + women } \\
\text { Men } \\
\text { Women }\end{array}$ & $\begin{array}{r}131 \\
43 \\
88\end{array}$ & $\begin{array}{l}4 \cdot 19(4 \cdot 66) \\
4 \cdot 24(5 \cdot 42) \\
4 \cdot 17(4 \cdot 35)\end{array}$ & $\begin{array}{l}5.43(3.90) \\
6.63(2.68) \\
4.93(4.51)\end{array}$ & $\begin{array}{l}4.30(4 \cdot 17) \\
5.85(2 \cdot 61) \\
3 \cdot 70(4 \cdot 91)\end{array}$ \\
\hline
\end{tabular}

There is no statistically significant $(p>0.05)$ difference between the two sexes.

*Geometric mean (geometric standard deviation).

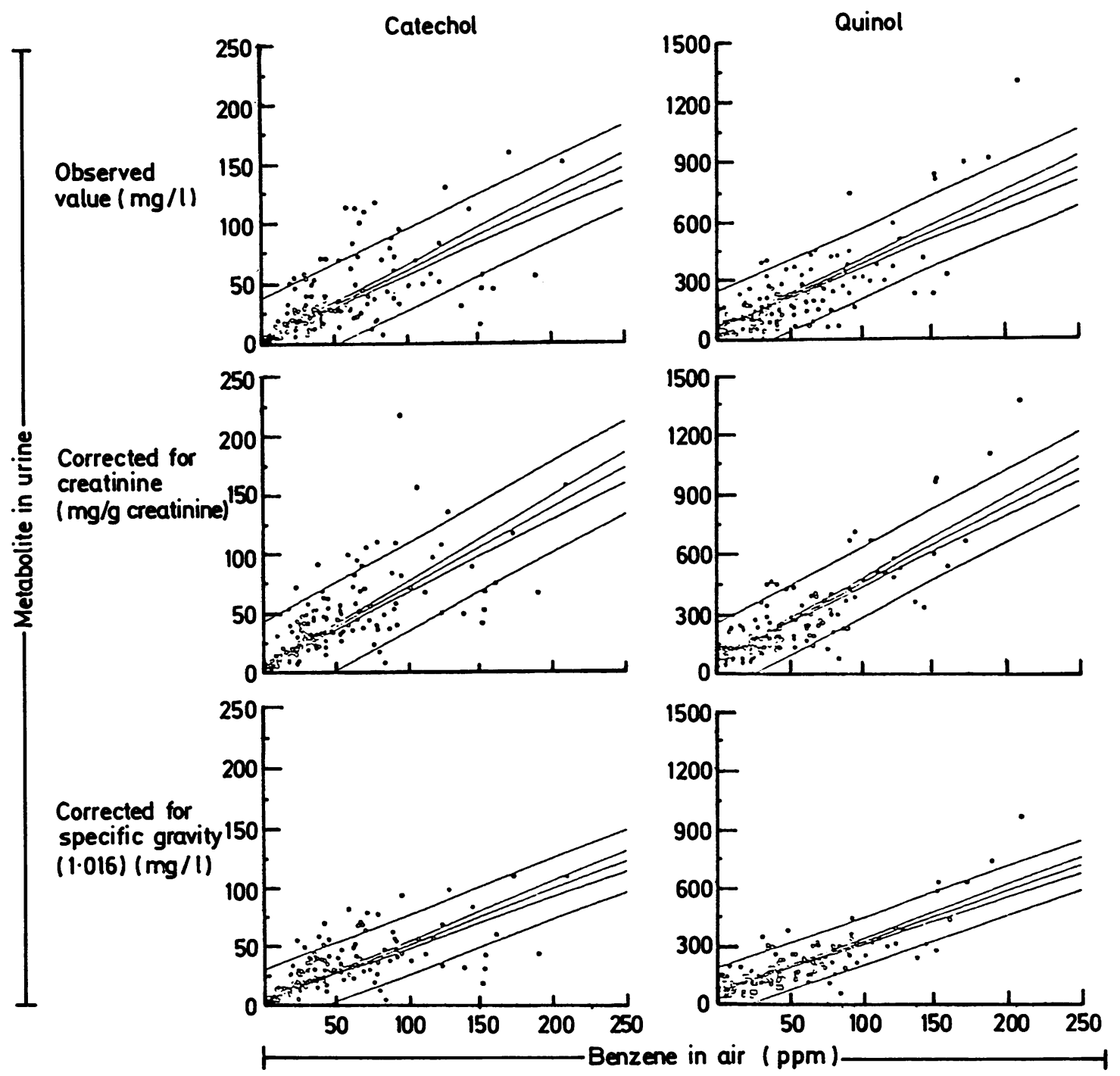

Fig 2 Relation between benzene in breathing zone air and metabolites (catechol and quinol) in urine. Points indicate individual values. Data from men and women are presented in combination. Lines and curves are calculated regression line (line in centre), $95 \%$ confidence ranges of sample means (curves close to regression line), and $95 \%$ confidence ranges of individual samples (outmost lines). 
LINEAR INCREASE OF CATECHOL AND QUINOL CONCENTRATIONS IN URINE AS A FUNCTION OF BENZENE CONCENTRATION IN BREATHING ZONE A I R

The concentrations of catechol and quinol in the urine of the exposed workers are tabulated by sex and by workshop in table 2 , in which the workshops are arranged in the increasing order of benzene concentration. Although the number of workers examined was small in some workshops, both metabolite concentra- tions increased with increasing benzene exposure. The quinol concentrations were several times higher than the catechol concentrations. The high quinol/catechol ratio resembles the results of an in vivo study in which rabbits were fed ${ }^{14} \mathrm{C}$-phenol ${ }^{14}$ and an in vitro assay in which ${ }^{14} \mathrm{C}$-phenol was incubated with rat liver microsomes $^{15}$ (with the quinol/catechol ratio $=10-20$ in both cases) rather than that of an in vivo ${ }^{14} \mathrm{C}$-benzene feeding study with rabbits (the quinol/ catechol ratio $=2$ ). ${ }^{1}$ Comparison with phenol concen-

Table 2 Concentrations of catechol and quinol in urine of workers exposed to benzene at various workshops

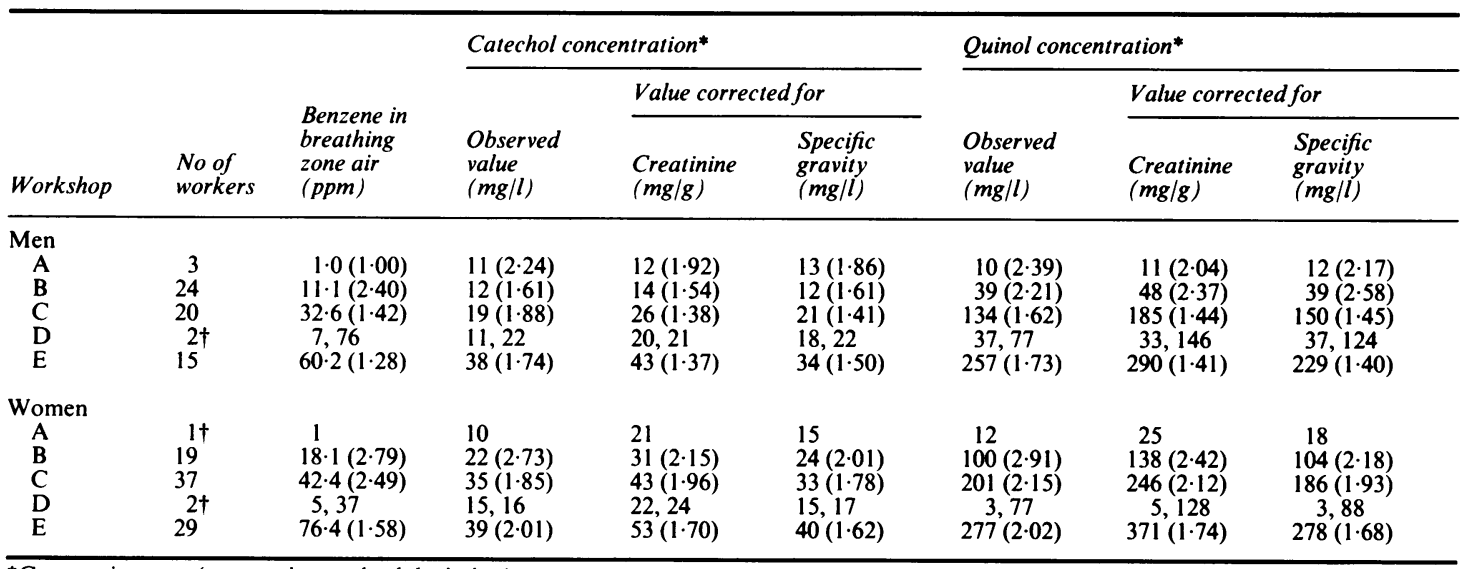

*Geometric mean (geometric standard deviation).

tIndividual values are shown.

Table 3 Correlation between breathing zone levels of benzene and urinary concentrations of catechol and quinol

\begin{tabular}{|c|c|c|c|c|c|c|c|}
\hline \multirow{2}{*}{$\begin{array}{l}\text { Measurement } \\
\text { group }\end{array}$} & \multirow{2}{*}{$\begin{array}{l}\text { No of } \\
\text { subjects* }\end{array}$} & \multicolumn{3}{|c|}{ Catechol } & \multicolumn{3}{|l|}{ Quinol } \\
\hline & & $A^{\dagger}$ & $B \dagger$ & $r \ddagger$ & $A \dagger$ & $B \dagger$ & $r \ddagger$ \\
\hline $\begin{array}{l}\text { Observed value (mg } \\
\text { Men + women } \\
\text { Men§ } \\
\text { Women } \| \\
\text { Women } \|\end{array}$ & $\begin{array}{l}283 \\
108 \\
175 \\
159\end{array}$ & $\begin{array}{l}0.537 \\
0.454 \\
0.546 \\
0.419\end{array}$ & $\begin{array}{r}10 \cdot 2 \\
9 \cdot 8 \\
11 \cdot 2 \\
13 \cdot 4\end{array}$ & $\begin{array}{l}0.808 \\
0.663 \\
0.831 \\
0.710\end{array}$ & $\begin{array}{l}3 \cdot 395 \\
3 \cdot 788 \\
3 \cdot 308 \\
4 \cdot 474\end{array}$ & $\begin{array}{l}24 \cdot 3 \\
12 \cdot 3 \\
29 \cdot 6 \\
14 \cdot 7\end{array}$ & $\begin{array}{l}0.793 \\
0.782 \\
0.792 \\
0.807\end{array}$ \\
\hline $\begin{array}{l}\text { Value corrected for } \\
\text { ine }(\mathrm{mg} / \mathrm{g}) \text { : } \\
\text { Men + women } \\
\text { Men } \S \\
\text { Women } \| \\
\text { Women }\end{array}$ & $\begin{array}{l}283 \\
108 \\
175 \\
159\end{array}$ & $\begin{array}{l}0.636 \\
0.411 \\
0.667 \\
0.569\end{array}$ & $\begin{array}{l}12.8 \\
13.7 \\
14.0 \\
15.6\end{array}$ & $\begin{array}{l}0.858 \\
0.745 \\
0.877 \\
0.763\end{array}$ & $\begin{array}{l}4 \cdot 025 \\
4 \cdot 049 \\
3 \cdot 992 \\
5 \cdot 774\end{array}$ & $\begin{array}{l}33 \cdot 6 \\
24 \cdot 3 \\
40 \cdot 0 \\
15 \cdot 1\end{array}$ & $\begin{array}{l}0.811 \\
0.794 \\
0.811 \\
0.843\end{array}$ \\
\hline $\begin{array}{l}\text { Value corrected for } \\
\text { gravity (mg/l): } \\
\text { Men + women } \\
\text { Men§ } \\
\text { Women\| } \\
\text { Women } \|\end{array}$ & $\begin{array}{l}283 \\
108 \\
175 \\
159\end{array}$ & $\begin{array}{l}0.426 \\
0.326 \\
0.440 \\
0.391\end{array}$ & $\begin{array}{l}11.3 \\
11.9 \\
11.7 \\
12.6\end{array}$ & $\begin{array}{l}0.851 \\
0.674 \\
0.879 \\
0.774\end{array}$ & $\begin{array}{l}2 \cdot 839 \\
3 \cdot 245 \\
2 \cdot 764 \\
4 \cdot 131\end{array}$ & $\begin{array}{l}29.5 \\
21 \cdot 8 \\
31 \cdot 6 \\
13.8\end{array}$ & $\begin{array}{l}0.821 \\
0.779 \\
0.831 \\
0.891\end{array}$ \\
\hline
\end{tabular}

*Including non-exposed subjects (43 men, 88 women).

+ Slope (A) and the intercept on the $Y$ axis $(B)$ in the equation as $Y=A X+B$, where $Y$ is the urinary concentration of catechol or quinol (unit; as described in the table) and $X$ is the breathing zone concentration of benzene (ppm).

$\ddagger p$ for correlation coefficient $(r)$ is $<0.01$ for all groups.

$\S$ Exposed up to $92 \mathrm{ppm}$.

IExposed up to $210 \mathrm{ppm}$.

qWomen exposed to less than $100 \mathrm{ppm}$. 
Table 4 Comparison of the lower $95 \%$ confidence limit of metabolite concentration in the urine of workers exposed to 10 ppm benzene with the upper $95 \%$ confidence limit of metabolite concentration of non-exposed subjects (number in parentheses)

\begin{tabular}{|c|c|c|c|}
\hline \multirow[b]{2}{*}{ Sex } & \multirow[b]{2}{*}{$\begin{array}{l}\text { Observed value } \\
\text { (mg/l) }\end{array}$} & \multicolumn{2}{|c|}{ Value corrected for } \\
\hline & & $\begin{array}{l}\text { Creatinine } \\
(\mathrm{mg} / \mathrm{g})\end{array}$ & $\begin{array}{l}\text { Specific gravity } \\
(\mathrm{mg} / \mathrm{l})\end{array}$ \\
\hline \multicolumn{4}{|c|}{ Catechol } \\
\hline $\begin{array}{l}\text { Men + women } \\
\text { Men } \\
\text { Women }\end{array}$ & $\begin{array}{ll}13.7 & (39.2) \\
11.7 & (38 \cdot 7) \\
13.9 & (39.5)\end{array}$ & $\begin{array}{ll}17 \cdot 3 & (37 \cdot 1) \\
15 \cdot 8 & (38 \cdot 1) \\
18 \cdot 1 & (36 \cdot 7) \\
\text { lol } & \end{array}$ & $\begin{array}{l}14.4(30 \cdot 7) \\
13 \cdot 3(31 \cdot 1) \\
14 \cdot 2(30 \cdot 4)\end{array}$ \\
\hline $\begin{array}{l}\text { Men + women } \\
\text { Men } \\
\text { Women }\end{array}$ & $\begin{array}{l}45.6(91.0) \\
35.6(124.6) \\
43.9(78.9)\end{array}$ & $\begin{array}{l}59 \cdot 4(82 \cdot 6) \\
48 \cdot 9(47 \cdot 6) \\
58 \cdot 3(100 \cdot 3)\end{array}$ & $\begin{array}{l}48 \cdot 3(74 \cdot 8) \\
41 \cdot 1(39 \cdot 9) \\
46 \cdot 0(89 \cdot 2)\end{array}$ \\
\hline
\end{tabular}

trations published in a preceding paper showed that the quinol concentrations were almost as high as that of phenol for all levels of benzene exposure. This observation in man differs from the findings of the benzene feeding study with rabbits in which the amount of phenol detected in urine was about five times higher than that of quinol. ${ }^{1}$

The relation between the benzene concentration in breathing zone air and the two metabolite levels in the urine was examined by pooling the data from the exposed and non-exposed subjects. The results are shown in fig 2; the data from men and women are shown in combination, with or without the correction for creatinine concentration and specific gravity. Although the scattering was rather wide in some cases-for example, quinol in female urine after correction for creatinine-there were significant $(p<0.01)$ linear correlations between exposure and the excretion of metabolites as shown in table 3. As some female workers were exposed to benzene up to $210 \mathrm{ppm}$ whereas the maximum concentration for men was $92 \mathrm{ppm}$, women exposed to less than $100 \mathrm{ppm}$ benzene were selected for the comparison of excretion between the two sexes. This indicated no sex difference in the biotransformation of benzene to these two metabolites.

Table 4 shows that the exposure to benzene at 10 ppm gave urinary excretion values that were overlapped by those of non-exposed subjects. The overlap is illustrated by the superimposition of urinary catechol and quinol concentrations of five women exposed to 9-14 ppm benzene on the histograms of 88 nonexposed women (fig 1).

As data on three major phenolic metabolites are made available by the combination of the present observations on catechol and quinol with the previous one on phenol, ${ }^{5}$ it is possible to make a quantitative cross sectional estimation of input-output balance on benzene metabolism in workers exposed to benzenefor instance, at $100 \mathrm{ppm}$ level. Assuming as in the previous paper that about $50 \%$ of benzene inhaled will be absorbed through the lungs, and that the rates of respiration and urine excretion will be $15 \mathrm{l} / \mathrm{min}$ and $1 \mathrm{ml} / \mathrm{min}$, respectively, the amount of benzene absorbed at $100 \mathrm{ppm}$ is $2392.5 \mu \mathrm{g} / \mathrm{min}$. The amount of benzene excreted in urine as catechol (quinol is in parentheses) is

$53.7(339.5) \mathrm{mg} / \mathrm{l} \times 1 \times 10^{-3} \mathrm{l} / \mathrm{min}$ $=53.7(339.5) \mu \mathrm{g} / \mathrm{min}$ or $38.1(240.8) \mu \mathrm{g} / \mathrm{min}$ as benzene

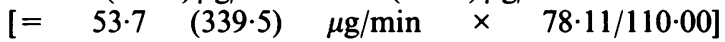
where $78 \cdot 11$ and $110 \cdot 11$ are the molecular weights of benzene and catechol or quinol, respectively. The calculated excretion of phenol is $316.7 \mu \mathrm{g} / \mathrm{min}$. $^{5}$ Thus $596 \mu \mathrm{g} / \mathrm{min}$ or about $25 \%$ of benzene absorbed is excreted in the form of these three urinary metabolites, of which $13 \%, 2 \%$, and $10 \%$ are as phenol, catechol, and quinol, respectively.

We are grateful to the Health Bureau of Hefei City and Dr S-L Fu, Ms R-G Zhang, Mr W-G Wu, Ms G-F Cui, Mr L-H Zai, Ms J-F Wan, Dr X-Z Wang, and Ms L-S Hong for their support and cooperation during the field study.

Requests for reprints to: Professor M Ikeda, Department of Environmental Health, Tohoku University School of Medicine, Sendai 980, Japan.

\section{References}

1 Parke DV, Williams RT. Studies in detoxication. 49. The metabolism of benzene containing $\left[{ }^{14} \mathrm{C}\right]$ benzene. $J$ Biochem 1953;54:231-8.

2 Lauwerys R. Industrial health and safety: human biological monitoring of industrial chemicals. I. Benzene. Luxembourg: Commission of European Communities, 1979:18-25.

3 Andrews LS, Sasame HA, Gillette J. ${ }^{3} \mathrm{H}$-Benzene metabolism in rabbit bone marrow. Life Sci 1979;25:567-72.

4 Irons RD, Dent JG, Baker TS, Rickert DE. Benzene is metabolized and covalently bound in bone marrow in situ. Chem Biol Interact 1980;30:241-5.

5 Inoue O, Seiji K, Kasahara M, et al. Quantitative relation of urinary phenol levels to breathzone benzene concentrations: a field survey. Br J Ind Med 1986;43:692-7.

6 Ikeda M, Hara I. Evaluation of the exposure to organic solvents by 
means of urinalyses for metabolites. Japanese Journal of Industrial Health 1980;22:3-17. (In Japanese with English abstract.)

7 Hirayama T, Ikeda M. Applicability of carbon felt to the dosimetry of solvent vapor mixture. Am Ind Hyg Assoc J 1979;90:1091-6.

8 Ikeda M, Ohtsuki T. Exposure concentration versus environmental concentration: a field survey in organic solvent workplaces. Tohoku J Exp Med 1985;146:225-35.

9 Ukai H, Ikeda M. Relationship between exposure and environmental concentrations in organic solvent workplaces. Tohoku J Exp Med 1986;149:251-60.

10 Greenlee F, Grass EA, Irons RD. Relationship between benzene toxicity and disposition of ${ }^{14} \mathrm{C}$-labelled benzene metabolites in the rat. Chem Biol Interact 1981;33:285-9.
11 Jackson $\mathrm{S}$ Creatinine in urine as an index of urinary excretion rate. Health Phys 1966;12:843-50.

12 Rainsford SG, Lloyd Davies TA. Urinary excretion of phenol by men exposed to vapour of benzene: a screening test. $\mathrm{Br} \mathrm{J}$ Ind Med 1965;22:21-6.

13 Ikeda $\mathbf{M}$, Ohtsuji $\mathbf{H}$. Hippuric acid, phenol and trichloroacetic acid in the urine of Japanese subjects with no known exposure to organic solvents. Br J Ind Med 1969;26:162-4.

14 Parke DV, Williams RT. Studies in detoxication. 54. The metabolism of benzene. (a) The formation of phenylglucuronide and phenylsulfuric acid from $\left[{ }^{14} \mathrm{C}\right]$ benzene. (b) The metabolism of $\left[{ }^{14} \mathrm{C}\right]$ phenol. J Biochem 1953;55:337-40.

15 Sawahara T, Neal RA. Biotransformation of phenol to hydroquinone and catechol by rat liver microsomes. Mol Pharmacol 1981;23:453-60.

\section{Vancouver style}

All manuscripts submitted to the $\mathrm{Br} J$ Ind Med should conform to the uniform requirements for manuscripts submitted to biomedical journals (known as the Vancouver style)

The $\mathrm{Br} J$ Ind Med, together with many other international biomedical journals, has agreed to accept articles prepared in accordance with the Vancouver style. The style (described in full in Br Med J, 24 February 1979, p 532) is intended to standardise requirements for authors.

References should be numbered consecutively in the order in which they are first mentioned in the text by Arabic numerals above the line on each occasion the reference is cited (Manson ${ }^{1}$ confirmed other reports $\left.{ }^{2-5} \ldots\right)$. In future references to papers submitted to the $\mathrm{Br} J$ Ind Med should include: the names of all authors if there are six or less or, if there are more, the first three followed by et al; the title of journal articles or book chapters; the titles of journals abbreviated according to the style of Index Medicus; and the first and final page numbers of the article or chapter.

Examples of common forms of references are:

I International Steering Committee of Medical Editors. Uniform requirements for manuscripts submitted to biomedical journals. Br Med J 1979;1:532-5.

2 Soter NA, Wasserman SI, Austen KF. Cold urticaria: release into the circulation of histamine and eosino-phil chemotactic factor of anaphylaxis during cold challenge. $N$ Engl $J$ Med 1976;294:687-90.

3 Weinstein L, Swartz MN. Pathogenic properties of invading micro-organisms. In: Sodeman WA Jr. Sodeman WA, eds. Pathologic physiology: mechanisms of disease. Philadelphia: W B Saunders. 1974:457-72. 